\title{
To Suppress or to Mitigate COVID-19: That is the Question
}

\author{
Anam Khan ${ }^{1}$, Allyson Goff ${ }^{2}$, Akram Ahmad ${ }^{3}$, Isha Patel ${ }^{4, *}$ \\ ${ }^{1}$ Independent Researcher, New Delhi, INDIA. \\ ${ }^{2}$ Department of Communication Sciences and Disorders, Ohio University, Ohio, USA. \\ ${ }^{3}$ Sydney Pharmacy School, The University of Sydney, Sydney, AUSTRALIA. \\ ${ }^{4}$ Department of Pharmacy Practice, Administration and Research, Marshall University School of Pharmacy, West Virginia, USA.
}

In India, public health experts have been debating the most effective way of combating COVID-19 (or SARS-COV-2 virus) while balancing the amount of lives lost and trying to preserve the economy. This virus is particularly challenging for India as the population is so large, and the healthcare system is still developing to meet the needs of its citizens. While social distancing has been and is being widely practiced worldwide to mitigate the further spread of COVID-19, it is apparent that more aggressive public health measures are needed to further decrease the numbers of infected people. Already, India has extended its lockdown from March $24^{\text {th }}$ to the end of May. ${ }^{[1]}$ By better understanding how this virus propagates, as well as by considering the unique needs of India, experts can better determine the best measures to fight further spread.

COVID-19 has primarily been shown to transmit between people through respiratory droplets and contact with objects used on or by an infected person; these objects or surfaces act as fomites. Some scientific publications provide initial evidence that there has been airborne transmission as well. ${ }^{[2,3]}$ Government officials and the media have often focused on this transmission, but a meta-analysis by the New England Journal of Medicine displays the abundance of studies elaborating on fecal-oral transmission of COVID-19. Gastrointestinal symptoms seem to be common symptoms of COVID-19, with a prevalence of $18 \%$ among all the infected and that fecal viral shedding continues throughout the disease and perhaps beyond its duration. ${ }^{[4,5]}$ Due to the multitude of possible ways to spread COVID-19, aggressive public health measures should be taken.

There seems to be a debate about two viable approaches to control the spread of COVID-19: suppression and mitigation. ${ }^{[6]}$ While suppression is essentially a drastic lockdown and sealing of COVID-19 hotspots, mitigation involves separating suspected cases, quarantining families with suspected cases and socially distancing those most vulnerable. Using an age-structured SIR model (Susceptible, Infected and Recovered) to study the variation in the number of infections in India, a single lockdown of 49 days would lower the number of infected people below ten. The study also anticipated that if no action would be taken, an expected 0.9 billion people would be infected, in total, with a peak infection of 167 million people in 114 days. ${ }^{[7]}$ Gabriel Leung, a public health expert from the University of Hong Kong, has suggested for countries to prepare themselves for several rounds of "suppress and lift" cycles ${ }^{[8]}$ This suggested cycle switches back and forth between enforcement of strict policies and relaxation thereof, in ways that can maintain the pandemic under control but at a reasonable economic and social cost. Leung's strategy is essentially a three-way compromise between preventing COVID-19 related deaths, sustaining the economy and allowing society to function normally. ${ }^{[9]}$ As opposed to the above approaches involving different techniques of implementing suppression, Jayaprakash Muliyil, a community health expert in India, propagates for mitigation over suppression. He says that in a nonorganized country like India, if complete suppression is employed, people will suffer and potentially die for various reasons besides the pandemic, such as starvation or other health emergencies. Therefore, Muliyil believes that the government's response must be rational when enforcing community suppression, and it should be considerate of all possible consequences that may arise from strict lock downs. Overcrowding in public places should be avoided, and symptomatic subset of COVID-19 patients who have difficulty breathing should hospitalised. Meanwhile, the non-symptomatic should be quarantined at home. Social distancing should continue for six to nine months. ${ }^{[10]}$

In India, the lockdown, which has been extended to the end of May, has already hit the Indian economy. As of May $10^{\text {th }}$, the unemployment rate is at $24 \%$, according to a report by the Center for Monitoring Indian Economy. ${ }^{[1]}$ The services industry, which has been hugely affected by the mass migration of workers back to their villages, remains suspended. The lockdown has occurred during harvest and planting seasons for many crops, which is when a multitude of laborers work on farms. A large challenge is helping farmers sell their crops, while also securing the future crops for the next season. ${ }^{[12]}$ Panic-buying from worried citizens is not assisting in economic growth. Rather, it ends up breaking social-distancing rules and destroying the supply chain. ${ }^{[13]}$ It is apparent that further lengthening this chaotic lockdown or initializing new lockdowns could have dire consequences. Overly strict social-distancing means that people are forced to stay at home and therefore cannot work. This is devastating for those who depend on a daily wage. The government can only support a large number of non-working citizens for so long. ${ }^{[14]} \mathrm{It}$ is for these reasons that mitigation is India's solution to managing the COVID-19 epidemic.

\section{REFERENCES}

1. BBC News. India extends coronavirus lockdown by two weeks. BBC News.

2. From: https://www.bbc.com/news/world-asia-india-52698828 Doremalen NV, Bushmaker T, Morris DH, Holbrook MG, Gamble A, Williamson BN, et al. Aerosol and Surface Stability of SARS-CoV-2 as Compared with SARS-CoV-1. N Engl J Med. 2020;382(16):1564-7.

3. World Health Organization. Modes of transmission of virus causing COVID-19: implications for IPC precaution recommendations. WHO. 2020. Retrieved from: https://www.who.int/news-room/commentaries/detail/modes-of-transmission-ofvirus-causing-covid-19-implications-for-ipc-precaution-recommendations

4. Cheung KS, Hung IF, Chan PP, et al. Gastrointestinal Manifestations of SARSCoV-2 Infection and Virus Load in Fecal Samples from the Hong Kong Cohort and Systematic Review and Meta-analysis. Gastroenterology. 2020. published online 26 March. https://doi.org/10.1053/j.gastro.2020.03.065 (pre-print).

5. Hindson, J. COVID-19: Faecal-oral transmission?. Nat Rev Gastroenterol Hepatol. 2020;17(5):259.

6. Nayar V. Locked down India struggles as workers flee cities and homeless call for food. BBC News. 2020. Retrieved from: https://www.bbc.com/news/av/ world-asia-india-52065968/locked-down-india-struggles-as-workers-flee-citiesand-homeless-call-for-food

7. Singh R, Adhikari R. Age-structured impact of social distancing on the COVID-19 
epidemic in India. ArXiv preprint arXiv 2003.12055. 2020. [Paper Presentation] COVID-19. Retrieved from: https://arxiv.org/pdf/2003.12055.pdf

8. Leung G. Lockdown Can't Last Forever. Here's How to Lift It. New York Times. 2020. Retrieved from: https://www.nytimes.com/2020/04/06/opinion/coronavirusend-social-distancing.html

9. Biswas S. Coronavirus: Why India cannot afford to lift its lockdown. BBC News. 2020. Retrieved from: https://www.bbc.com/news/world-asia-india-52222906

10. Scroll. Interview: 'Suppression won't work in India. Slow down the coronavirus. This will be a long haul'. Scroll.in. 2020. Retrieved from: https://scroll.in/ article/956932/interview-suppression-wont-work-in-india-slow-down-thecoronavirus-this-will-be-a-long-haul

11. Sharma YS. 27 million youth in age group of $20-30$ years lost jobs in April: CMIE.
The Economic Times. 2020. Retrieved from: https://economictimes.indiatimes. com/news/economy/indicators/unemployment-rate-dips-to-23-97-data-from-cmieshows/articleshow/75689370.cms?from $=\mathrm{mdr}$

12. Singh A. COVID-19 Outbreak: Rural India stares at a larger crisis. Deccan Herald. 2020. Retrieved from: https://www.deccanherald.com/business/covid19-outbreak-rural-india-stares-at-a-larger-crisis-821866.html

13. Special Correspondent. India coronavirus lockdown and Grocers scramble to restock after night of panic buying. The Hindu. 2020. Retrieved from: https://www. thehindu.com/news/cities/Delhi/grocers-scramble-to-restock-after-night-of-panicbuying/article31167791.ece

14. Vaidyanathan G. People power: How India is attempting to slow the coronavirus. Nature. 2020;580(7804):442.

Received: 24 April 2020;

Accepted: 19 May 2020

*Correspondence to:

Dr. Isha Patel

Department of Pharmacy Practice, Administration and Research, Marshall University School of Pharmacy, West Virginia, USA.

Email: pateli@marshall.edu

Copyright: (C) the author(s),publisher and licensee Indian Academy of Pharmacists. This is an open-access article distributed under the terms of the Creative Commons Attribution Non-Commercial License, which permits unrestricted non-commercial use, distribution, and reproduction in any medium, provided the original work is properly cited.

Cite this article as: Khan A, Goff A, Ahmad A, Patel I. To Suppress or to Mitigate COVID-19: That is the Question. J Pharm Pract Community Med. 2020;6(2):20-1. 